$\mathrm{Oz}$

Volume 38

Article 9

$1-1-2016$

\title{
Museum of Contemporary Art and Planning Exhibition. Shenzhen, China (2007-2016)
}

Wolf D. Prix

Coop Himmelb(I)au

Follow this and additional works at: https://newprairiepress.org/oz

Part of the Architecture Commons

(c) (i) $(9)$

This work is licensed under a Creative Commons Attribution-Noncommercial-No Derivative Works 4.0 License.

\section{Recommended Citation}

Prix, Wolf D. (2016) "Museum of Contemporary Art and Planning Exhibition. Shenzhen, China (2007-2016)," Oz: Vol. 38. https://doi.org/10.4148/2378-5853.1558

This Article is brought to you for free and open access by New Prairie Press. It has been accepted for inclusion in Oz by an authorized administrator of New Prairie Press. For more information, please contact cads@k-state.edu. 


\section{Museum of Contemporary Art and Planning Exhibition}

Shenzhen, China (2007-2016)

\section{Coop Himmelb(l)au \\ Wolf D. Prix and Partner ZT GmbH}

The Museum of Contemporary Art and Planning Exhibition (MOCAPE) is part of the master plan for the Futian Cultural District, the new urban center of Shenzhen. The project combines two independent yet structurally unified institutions: The Museum of Contemporary Art (MOCA) and the Planning Exhibition (PE) as a cultural meeting point and a venue for architectural exhibitions. The lobby, multifunctional exhibition halls, auditorium, conference rooms and service areas will be used jointly.

Both museums are designed as separate entities emphasizing their individual functional and artistic requirements and yet are merged in a monolithic body surrounded by a multifunctional facade. This transparent facade and a sophisticated internal lighting concept allow a deep view into the joint entrance and transitional areas between the buildings. From the inside, visitors are granted an unhindered view onto the city suggesting they are somewhere in a gently shaded outdoor area, an impression enhanced by 6 - to 17-meter high, completely open and column-free exhibition areas.

Behind the entrance area between the museums, visitors ascend to the main level by ramps and escalators and enter the "Plaza," which serves as a point of departure for tours of the museums. From the Plaza the rooms for cultural events, a multifunctional hall, several auditoriums
A silvery, shining and softly-deformed "Cloud" serves as a central orientation and access element on the Plaza. On several floors the Cloud hosts a number of public functions such as a cafe, a book store, and a museum store and it joins the exhibitions rooms of both museums with bridges and ramps. With its curved surface the Cloud opens into the space reflecting the idea of two museums under one roof.
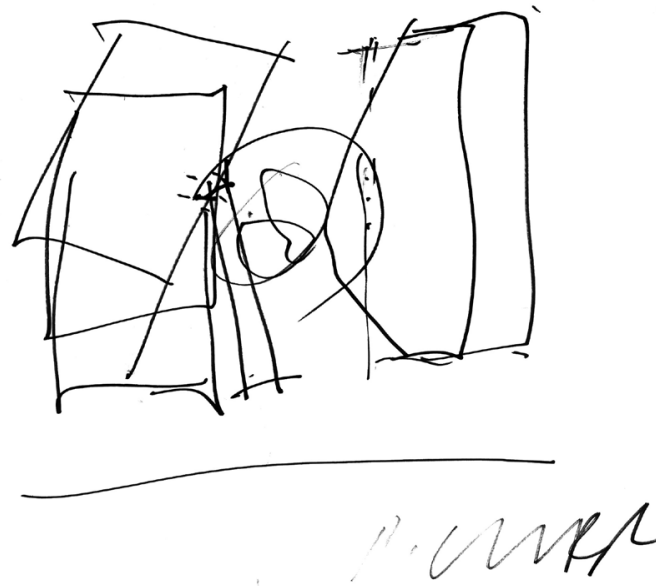

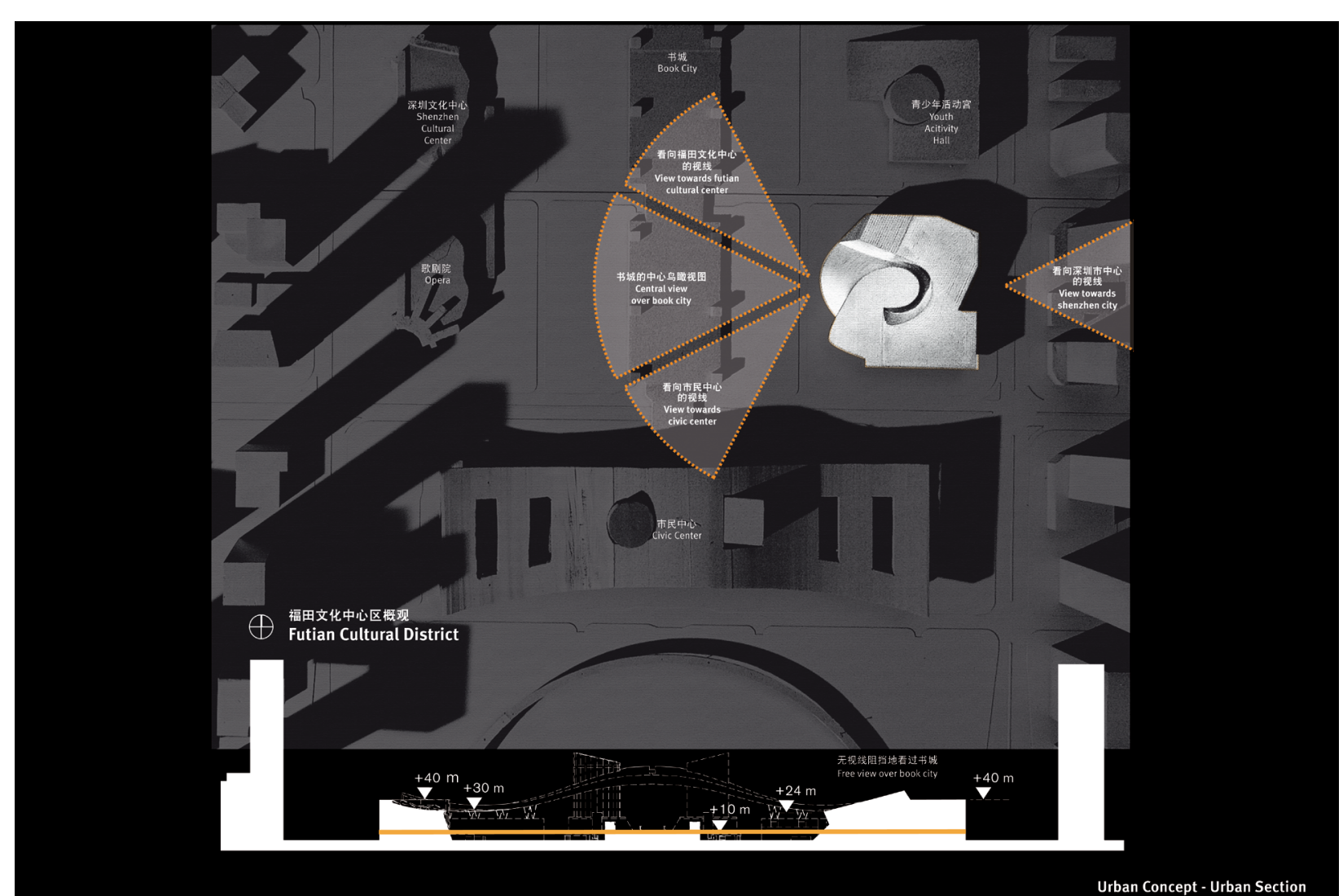



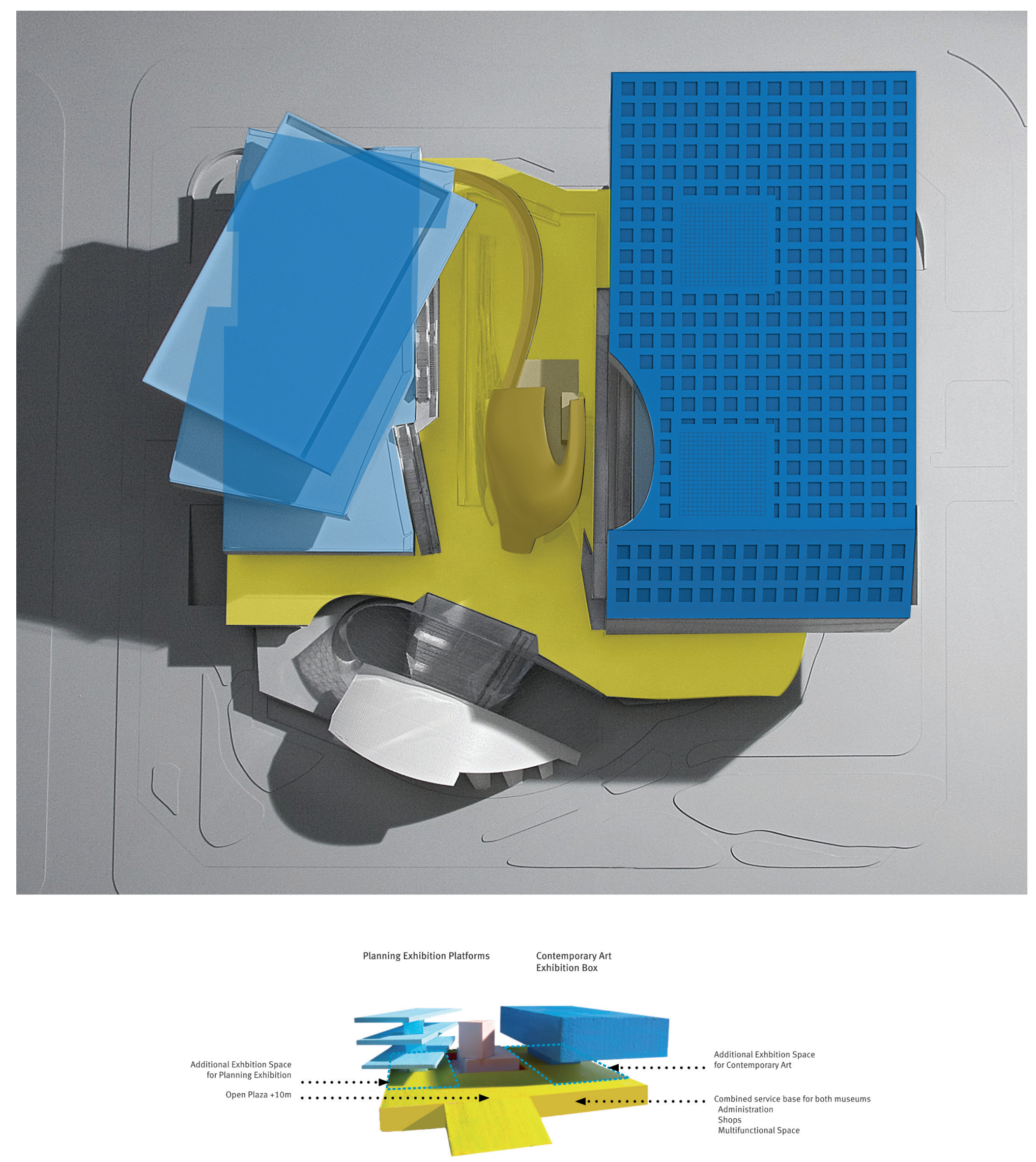

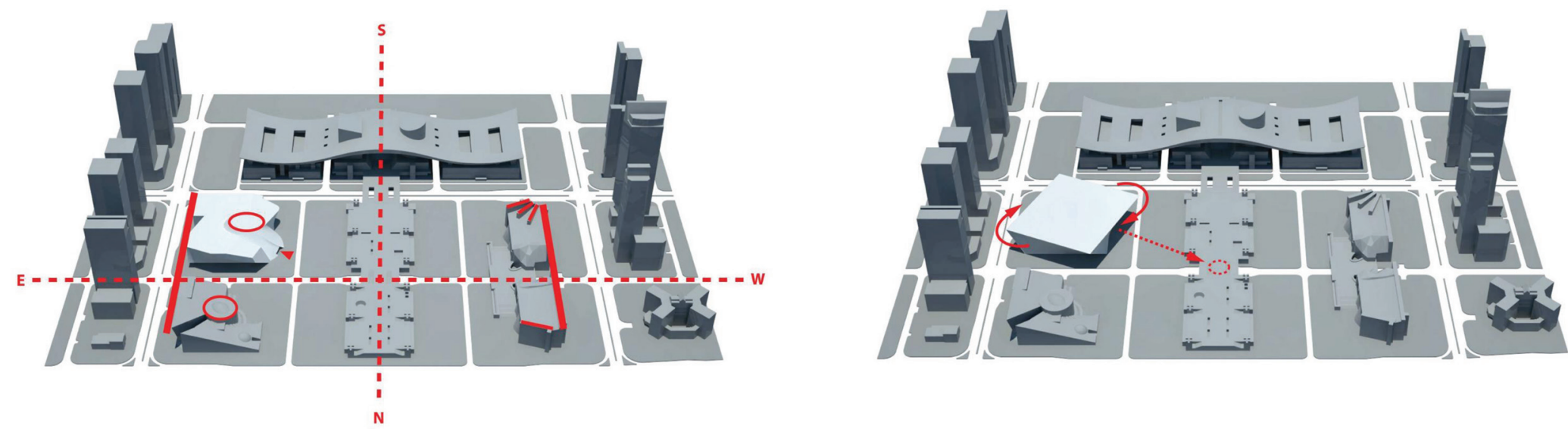

Adaption to urban symmetry

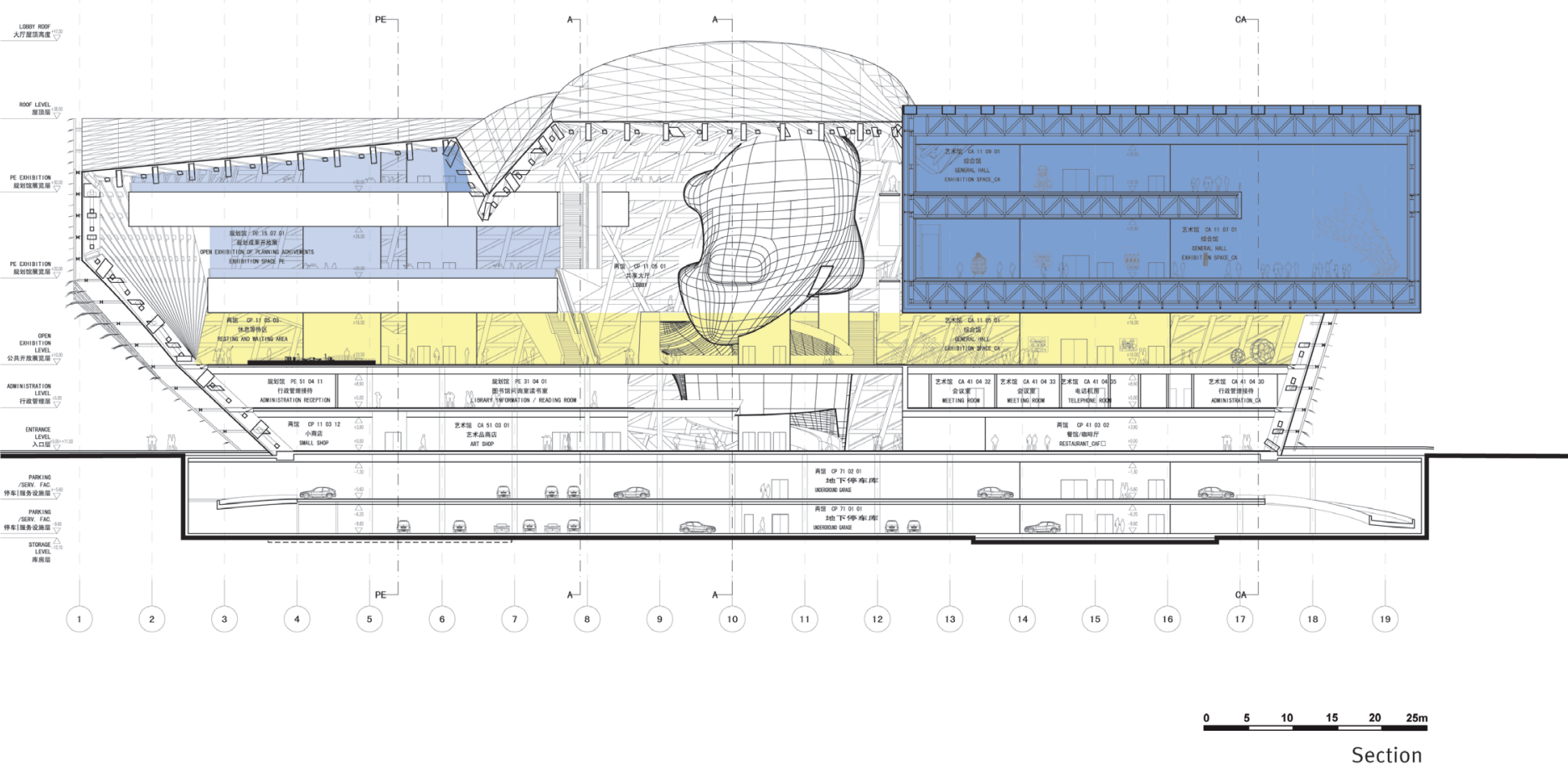



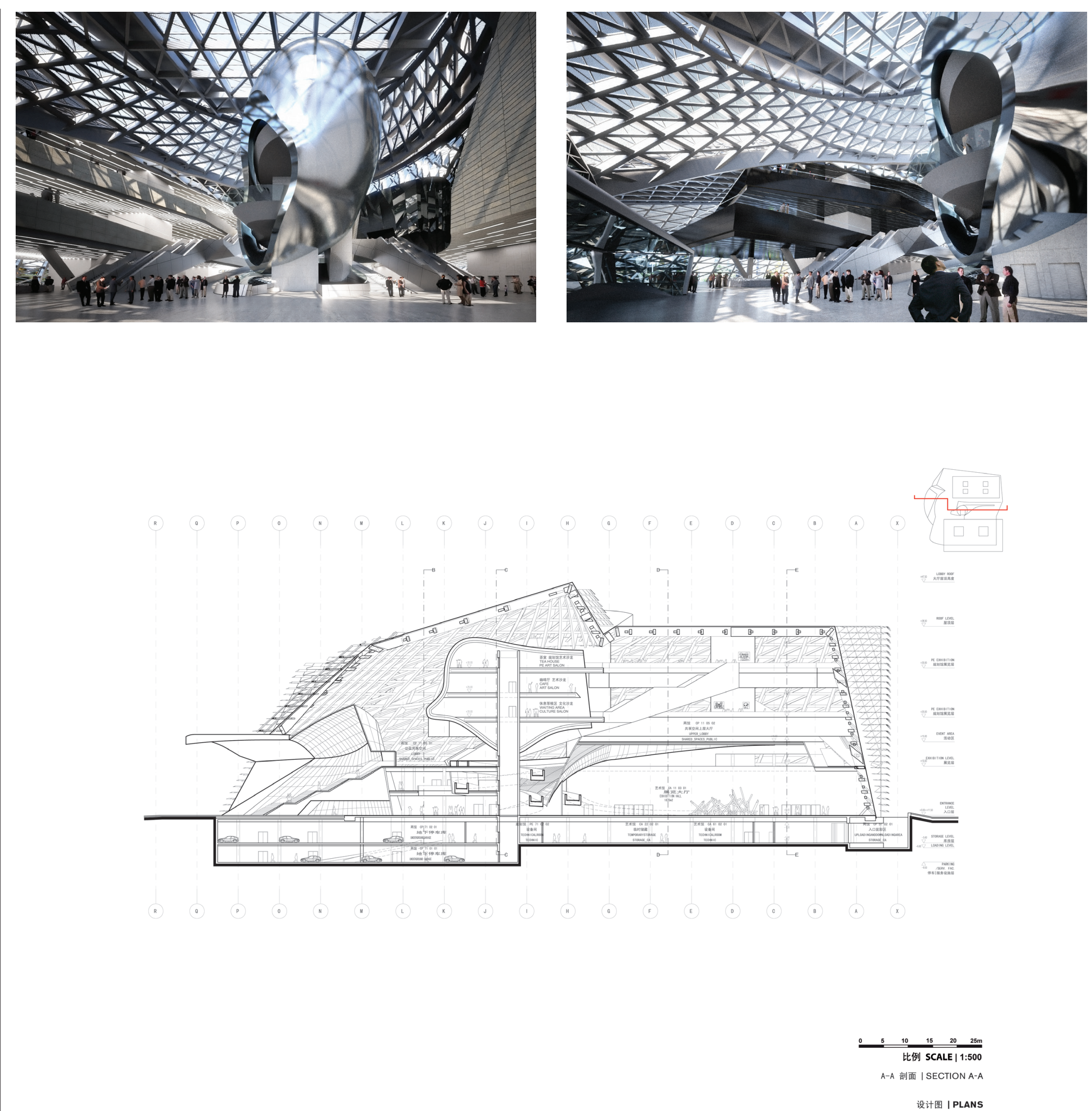


\section{The Urban Concept}

The MOCAPE monolith completes the eastern part of the master plan for the city center and fills the last gap in the Futian Cultural District between the Youth Activity Hall (YAH) to the north and the opera-library complex to the south.

Similar to other buildings in this district, the main level of the MOCAPE lies 10 meters above the ground leve and, so, creates a stage-like platform, which acts as a unifying element with the adjacent buildings.

\section{Skin, Light, and Energy Concept}

The exterior skin consists of an outer layer of natural stone louvers and the actual climate envelope made from insulated glass. These elements form a dynamic surface, which is structurally independent from the mounting framework of the museum buildings. This functional exterior envelops the two museums, a vertical access and entertainment element (the Cloud) the public Plaza, and the multifunctional base.

The technical building equipment is designed to reduce the overall need of external energy sources. Pollution-free systems and facilities use renewable energy sources through solar and geothermal energy (with a ground water cooling system) and only systems with high-energy efficiency have been implemented. The roof of the museum filters daylight for the exhibition rooms, which reduces the need for artificial lighting.

With this combination of state-ofthe-art technological components, a compact building volume, thermal insulation, and efficient sun shading the MOCAPE is not only an architectural landmark but also an ecological and environmentally friendly benchmark project.

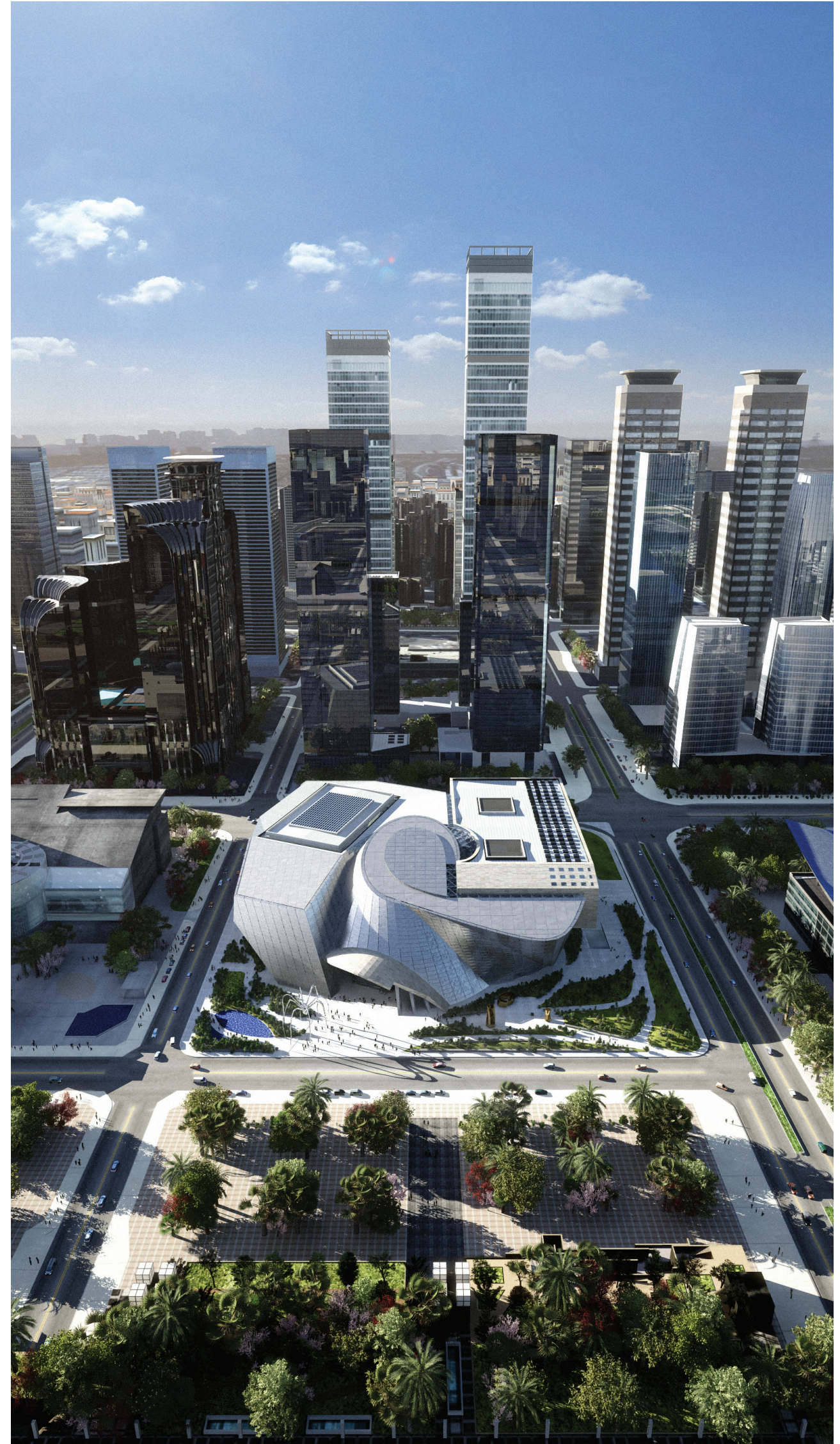



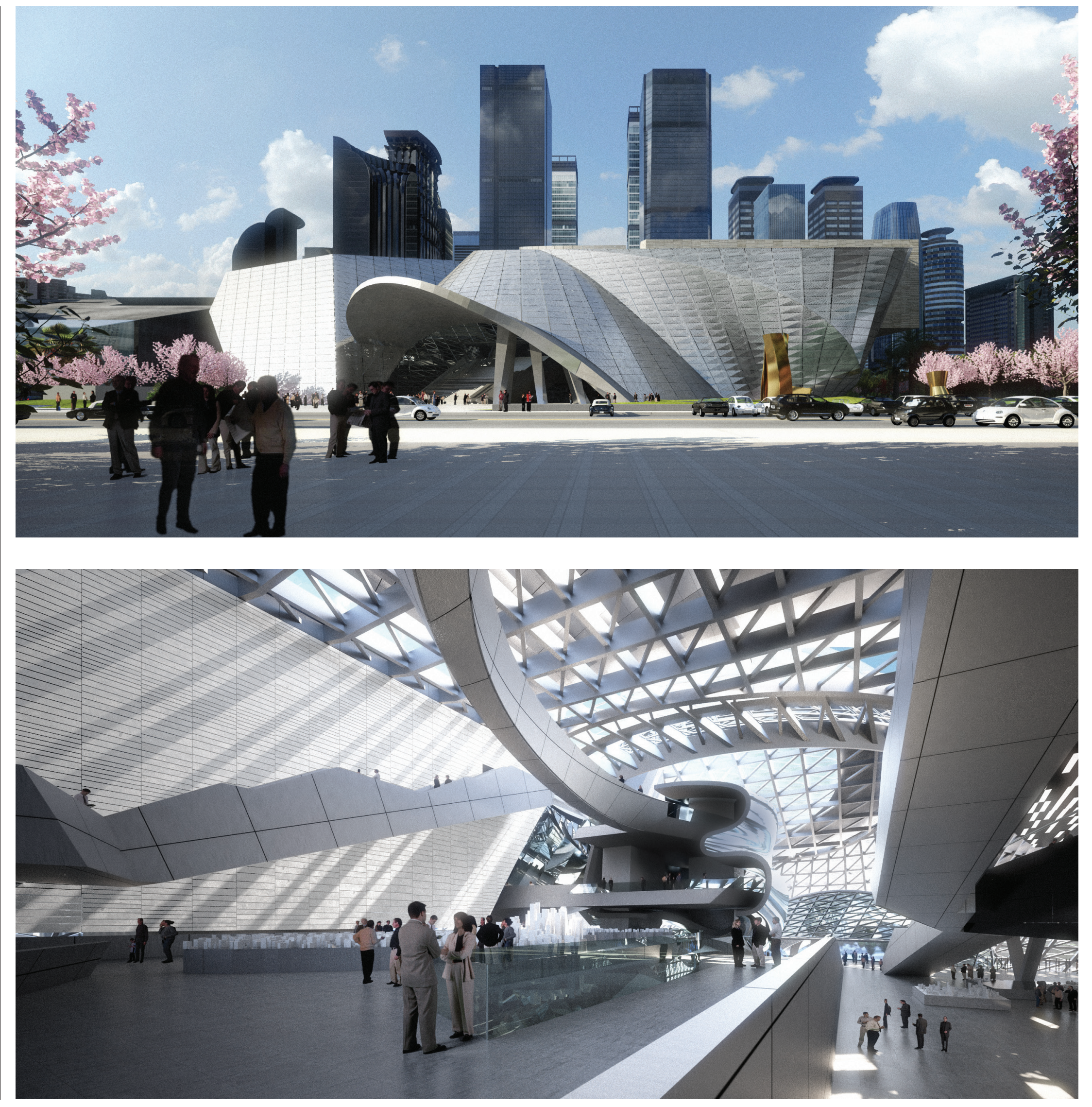